\title{
Online Shopping Malls: Behavioral Impacts of Short- and Long-Term Store Loyalty
}

\author{
Yukihiro Miwa ${ }^{1}$, Makoto Morisada ${ }^{1}$, Wirawan D. Dahana ${ }^{1}$ \\ ${ }^{1}$ Gradute School of Economics, Osaka University, Japan \\ Correspondence: Wirawan D. Dahana, Graduate School of Economics, Osaka University, Toyonaka, Osaka, \\ Japan.
}

Received: January 2, 2018

Accepted: January 18, 2018

Online Published: February 2, 2018

doi:10.5539/ibr.v11n3p10

URL: https://doi.org/10.5539/ibr.v11n3p10

\begin{abstract}
This study addresses how customers develop loyalty toward focal stores within an online shopping mall, and how this construct affects behavioral mall loyalty in both the short- and long-term. We employ a type II Tobit model to dynamically capture the short- and long-term impacts of store loyalty on purchase incidence and purchase amount. We further embed this model within a model of store loyalty formation to elucidate its driving factors. Applying the models to purchase history data of new customers in an online shopping mall, we observe that store loyalty has an immediate negative effect on purchase incidence; however, given a purchase, this variable increases the purchase amount in the long-term. Additionally, the formation of store loyalty appears to be significantly affected by gender, age, cumulative purchase amount, cumulative purchase frequency, and time trend. We discuss the implications of these findings for mall owners in an effort to increase revenue contribution of their tenants.
\end{abstract}

Keywords: online shopping mall, purchase amount, purchase incidence, store loyalty, Tobit model

\section{Introduction}

The last decade has witnessed a remarkable growth of online shopping malls in many countries. For example, in the United States, 43\% of all online retail sales went through Amazon in 2016 (Business Insider, 2017), whereas in Japan, Rakuten accounted for $25.6 \%$ of total e-commerce sales in the same year. The rapid growth of these giant e-retailers is attributable to high profitability, most of which stems from revenues gained from their tenant shops (Adkins Lehew, Burgess, \& Wesley, 2002). For this reason, it is important for mall owners to understand how the relationships between their customers and tenants could alter long-term profitability. In particular, it is critical to address how customer loyalty toward focal stores could affect buying behavior, and eventually loyalty toward the mall as a whole.

In the literature, there is a growing interest in the antecedents and consequences of customer loyalty in online shopping malls. Numerous researchers have investigated the potential factors that could influence the formation of customer loyalty in an online market (Kim, Jin, \& Swinney, 2009; Semeijn, van Riel, van Birgelen, \& Streukens, 2005; Srinivasan, Anderson, \& Ponnavolu, 2002; Wu, Chen, Chen, \& Cheng, 2014). Further, Kim and Shim (2002) shed light on the influence of online shopping mall characteristics on customer buying behavior. Similarly, Koo (2006), along with Lin and Sun (2009), examine the explanatory power of the same variables on customers' mall loyalty. Despite the increasing number of studies on this topic, the association between mall and store loyalty in an online market has not been adequately addressed. In fact, Majumdar (2005) suggests that in the traditional shopping mall context, customer loyalty toward a mall could strengthen the loyalty toward a specific tenant shop. Further, Rabbanee, Ramaseshan, Wu, and Vinden (2012) point out that favorable attitudinal loyalty toward certain stores within a traditional mall can lead to favorable attitudinal mall loyalty. These empirical findings indicate that it is plausible to anticipate the causal relationship between mall and store loyalty in the online context.

In this study, we aim to address how store loyalty can affect customer buying behavior in an online shopping mall (i.e., behavioral mall loyalty). The focus is on both the short- and long-term effects of store loyalty on purchase incidence and purchase amount. We also investigate the process in which store loyalty is developed over time, along with its determinants, including demographic variables and past purchase experiences. Based on past studies, we build hypotheses concerning these relationships and test them by using purchase history data of 
new customers in an online shopping mall. The results reveal that short-term loyalty has a negative effect on purchase incidence; however, in the long-term, this variable appears to increase the purchase amount in each transaction. Further, we find the significant effects of gender, age, cumulative purchase amount, and cumulative purchase frequency on the formation of long-term store loyalty.

The contributions of this study are threefold. First, to our knowledge, this study is the first to investigate the association between store and mall loyalty in an online market. Thus, the analysis could provide external validity concerning previous findings in a traditional shopping mall. Second, the decomposition of store loyalty effect into short- and long-term effects enables us to capture how the evolution of this variable would impact purchase frequency and purchase amount over time. Finally, we expect findings from this study to be useful for mall owners in an effort to better understand how the relationships between their customers and tenants could lead to a change in company revenue.

The remainder of this paper is structured as follows. In Section 2, we review previous studies related to mall and store loyalty. Subsequently, Section 3 describes the analytical framework of this study and states the hypotheses. Sections 4 and 5 illustrate the proposed model and the data used in the empirical analysis, respectively. In Sections 6 and 7, we report the estimation results and discuss the managerial implication, respectively. Finally, in Section 8 , we provide the concluding remarks and limitations of this study.

\section{Literature Review}

The concept of store loyalty has been well documented in the literature. From a marketer's point of view, store loyalty is an important variable that can positively affect customers' purchase amount and purchase frequency (Umashankar, Bhangwat, \& Kumar, 2017). In shopping malls, customer loyalty toward certain focal stores is crucial because of its potential influence on both store sales and mall profitability (Babin \& Attaway, 2000), as tenant shops usually offer product assortments that are imperfect substitutes to each other (Haytko \& Baker, 2004). Researchers distinguish store loyalty from mall loyalty, in which the latter can be defined as a shopper's attitudinal predisposition consisting of intentions to continually patronize the mall through repeat shopping (Chebat, Hedhli, \& Sirgy, 2009). According to Hedhli, Chebat, and Sirgy (2013), the formation of mall loyalty is influenced by the ease of access to a mall and the ability of a mall to provide customers with products that meet their needs. Further, Haj-salem, Chebat, Michon, and Oliveira (2016) indicate that the formation of mall loyalty is different between male and female customers; that is, while male customers' loyalty is likely to be driven by prices, female customers rely on their perceived value of product offerings in developing mall loyalty.

Few researchers have attempted to investigate the association between store and mall loyalty in traditional shopping malls. For example, using data of Indian customers, Majumdar (2005) revealed that higher mall loyalty leads to higher store loyalty. In fact, in an effort to gain loyal customers, it is common for mall owners to assist their tenants by undertaking product recommendations (Hendershott, Hendershott, \& Hendershott, 2001) or providing attractive shopping experiences (Haytko \& Baker, 2004). As a result, customers who have strong mall loyalty would perceive less risk when shopping at unfamiliar stores within the mall.

Unlike traditional shopping malls, online shopping malls have several distinct features. First, while the number of stores is limited by mall capacity in traditional malls (Corstjens \& Lal, 2000), online shopping malls can virtually have an 'unlimited' number of tenants. Moreover, the stores in online shopping malls can virtually sell a large variety of products on an e-commerce site because there is almost no restriction of product inventory. Second, to facilitate shopping behavior of their customers, mall owners can flexibly rearrange the layout of their websites at a lower cost (Hendershott et al., 2001). Finally, customers can access online shopping malls to shop from anywhere by using Internet-connected devices. Researchers point out that mall owners can leverage these features to enhance the loyalty toward the mall, as well as toward the stores (Ahn, Ryu, \& Han, 2003; Koo, 2006).

Yet, the investigation into how customers develop loyalty in online shopping malls is still sparse. Among the few available studies, Koo (2006), along with Lin and Sun (2009), try to identify several determinants of customer loyalty toward online shopping malls. However, these studies do not account for the role of store loyalty. As previously mentioned, store loyalty can have a positive effect on customers' mall loyalty in traditional shopping malls (Rabbanee et al., 2012), but it is still unclear whether this finding holds in the context of an online market. Further, the extant literature has not addressed whether or how store loyalty would affect customer buying behavior in both the short- and long-term. 


\section{Analytical Framework and Hypotheses}

\subsection{Overview}

Figure 1 shows the analytical framework of this study. As previously outlined, our main objective is to examine the potential effects of store loyalty on mall loyalty of online shopping mall customers. Additionally, we investigate how store loyalty is affected by customer demographics and other behavioral variables. We define store loyalty as the biased behavioral response (i.e., repurchase) by customers with respect to some focal stores out of hundreds of stores within a mall (Bloemer \& Ruyter, 1998). Here, focal stores refer to stores that are frequently used by a customer and account for more than $60 \%$ of share of wallet. We distinguish between shortand long-term store loyalty to capture its immediate and dynamic effects on customer behavior. The former concerns the immediate effect of previous relative spending in the focal stores, whereas the latter refers to the carry-over effect of relative store visits in the focal stores over a longer time period. In so doing, we expect that successive purchase behaviors would be affected by store choice behavior in the current period. If customers are satisfied with the focal stores, this should render favorable impacts on future purchase probability or purchase amount (Swinyard, 1993).

The basic premise of this study is that if a customer continues to patronize the focal stores for a long period, she or he is expected to perceive a higher switching cost when shopping in unfamiliar stores. In this case, the risk perceived by the customer will be high (Stranahan \& Kosiel, 2007), but eventually results in a lower purchase intention in the stores (Samadi \& Yaghoob-Nejadi, 2009). Therefore, in the long-term, customer purchases are likely to concentrate in a few focal stores, and we anticipate that this tendency will affect the way customers spend money in a mall, and the extent to which they intend to repurchase. The notion that store loyalty can affect purchase probability and purchase amount, which we treat as behavioral indicators of mall loyalty, is consistent with the findings reported by Rabbanee et al. (2012). However, in contrast to the study, we model the effects of store loyalty on mall loyalty in a dynamic manner, and empirically examine the model using actual purchase history data.

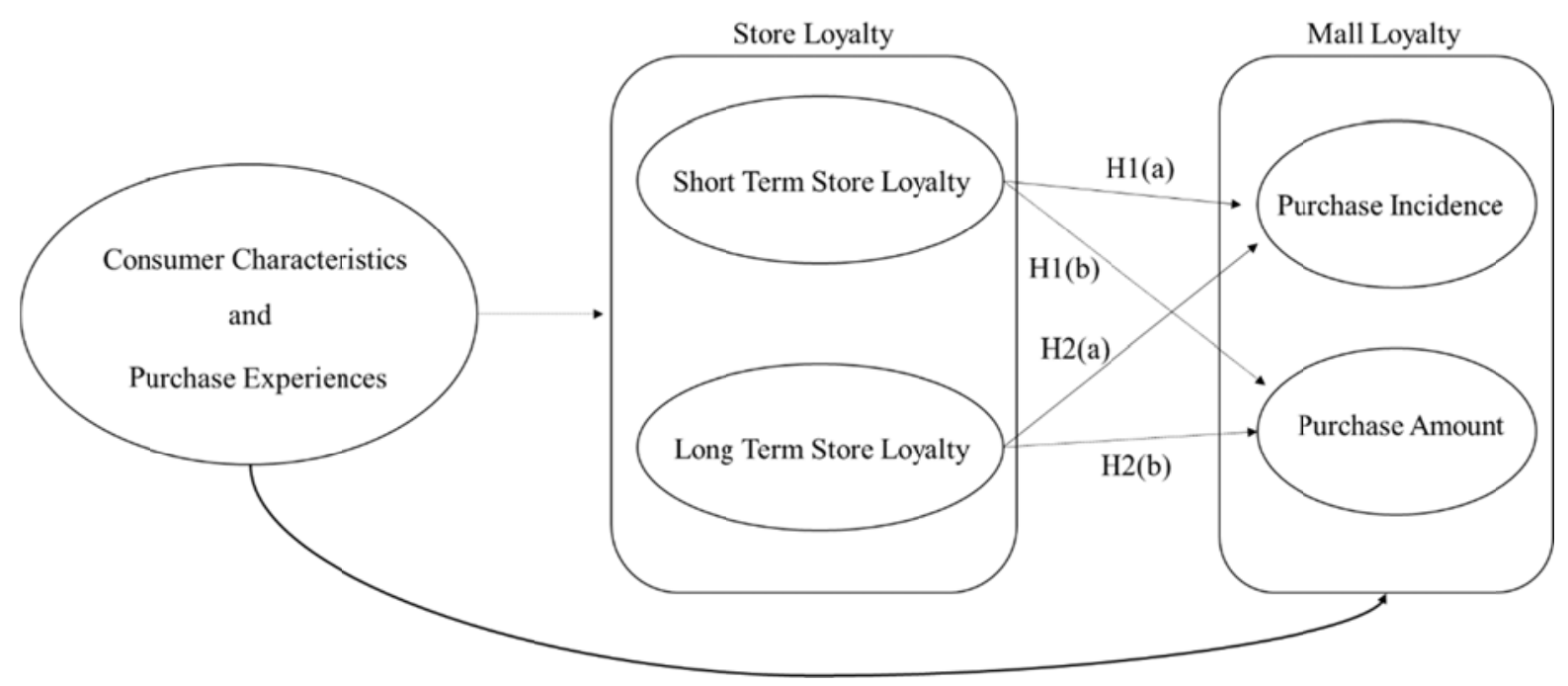

Figure 1. Analytical Framework

In addition, we explore how store loyalty evolves over time by accounting for the potential effect of demographic variables and past purchase experiences. Studies provide evidence that cognitive processes and behavioral patterns are heterogeneous among customers with different gender and age (Fisher \& Dubé, 2005; Lian \& Yen, 2014; Meyers-Levy \& Maheswaran, 1991; Meyers-Levy \& Sternthal, 1991). Therefore, we presume that the difference may also apply to the case of store loyalty formation, provided that the process involves customer evaluation of products offered by stores in which they are purchased. Further, as suggested by Swinyard (1993), the quality of past buying experiences may influence customers' future purchase intentions. Thus, we expect store loyalty to be partially driven by past experience variables, which are operationalized as cumulative purchase frequency and cumulative purchase amount. Furthermore, since our focus is on online customers, we consider the effect of the type of device used by customers to access the mall's website. A previous study by Wang, Malthouse, and Krishnamurthi (2015) indicates that mobile device users are more likely to purchase more frequently and order higher quantities than those who use fixed PCs when buying online. 
Finally, because loyalty is negatively correlated with price consciousness (Ailawadi, Pauwels, \& Steenkamp, 2008), we anticipate that the extent to which customers buy products on promotion will have a negative effect on store loyalty formation.

\subsection{Hypotheses}

\subsubsection{The Effects of Short-Term Store Loyalty}

Researchers have used behavioral metrics, such as purchase amount and probability, repeat purchases, and buying pattern, as surrogates for true customer loyalty (Kumar \& Shah, 2004). In online shopping malls, where there are a large number of tenant shops, customers may exhibit favorable attitudes toward, and frequently buy at, multiple stores (i.e., focal stores). In this study, we define short-term store loyalty as the percentage of purchase amount spent at the focal stores in the previous purchase occasion. Higher short-term store loyalty is a sign of temporal customer satisfaction toward focal stores. That is, loyal customers may perceive focal stores as offering higher quality and value, or better prices relative to its competitors (Sirohi, McLaughlin, \& Wittink, 1998). This satisfactory buying experience in focal stores should enhance subsequent customer purchase intention and behavior in the mall (Swinyard, 1993). In other words, short-term store loyalty should increase purchase probability and purchase amount in the subsequent purchase occasion. Hence,

H1(a): Short-term store loyalty positively affects subsequent purchase incidence.

H2(a): Short-term store loyalty positively affects subsequent purchase amount.

\subsubsection{The Effects of Long-Term Store Loyalty}

Long-term store loyalty refers to repetitive purchasing behavior at focal stores over a longer time period. This variable captures the cumulative experiences of customers and focal stores; thus, reflecting favorable relationships between the two parties. Research studies suggest that long-term store loyalty entails a high level of satisfaction and trust (Bloemer \& Ruyter, 1998; Garbarino \& Johnson, 1999; Kumar, Pozza, \& Ganesh, 2013; Mittal \& Kamakura, 2001). Note that in online shopping malls, there are numerous stores for which customers are unfamiliar. Typically, customers perceive higher risk when making a purchase in unfamiliar stores (Stranahan \& Kosiel, 2007), which leads to lower purchase intention (Samadi \& Yaghoob-Nejadi, 2009). Thus, the switching cost should be high for customers who are satisfied with, or trust in, certain focal stores. Further, since satisfaction is positively associated with store image (Bloemer \& Ruyter, 1998), and store image is positively associated with shopping mall image (Finn \& Louviere, 1996), it can be argued that long-term store loyalty should result in a better perception of the mall. Erdil (2015) asserts that positive image decreases perceived risk of online shopping, which eventually positively affects purchase frequency and purchase amount. Hence,

H1(b): Long-term store loyalty positively affects subsequent purchase incidence.

H2(b): Long-term store loyalty positively affects subsequent purchase amount.

\section{Model}

In this section, we describe a stochastic model to delineate the relationship between store loyalty and mall loyalty, as well as the influencing factors of store loyalty formation. We employ a type II Tobit model to examine the effect of store loyalty on purchase incidence and purchase amount. This model is frequently used in marketing research to analyze censored data (Ansari, Mela, \& Neslin, 2008). Here, we apply this modeling to the customer decision of whether or not to purchase in each period, and if so, how much to spend.

We let $b_{i t}$ be an indicator function concerning whether or not customer $i$ makes a purchase at time $t$. Given a purchase, the log of amount spent by the customer is denoted by $p_{i t}$. Denoting the latent utility of making a purchase by $b_{i t}^{*}$, we have the following equations:

$$
\begin{gathered}
b_{i t}=\left\{\begin{array}{cc}
\text { Buy } & \text { if } b_{i t}^{*}>0 \\
\text { No Buy } & \text { if otherwise }
\end{array}\right. \\
p_{i t}=\left\{\begin{array}{cl}
\text { Purchace amount } & \text { if } b_{i t}^{*}>0 \\
0 & \text { if otherwise }
\end{array}\right.
\end{gathered}
$$

Further, we denote (long-term) customer store loyalty up to purchase occasion $t$ by $s l_{i t}$. This variable reflects the formation of customer store loyalty over time. We operationalize this variable as follows: 


$$
s l_{i t}=1-\frac{\text { store }_{i t}}{\text { Freq }_{i t}}
$$

Here, Store $_{i t}$ and Freq $_{i t}$ are the cumulative number of stores the customer shopped in and the cumulative purchase frequency, respectively. Verifiably, this variable ranges from 0 to 1 , where a higher value corresponds with higher store loyalty. If a customer buys at different stores every time she or he makes a purchase, this variable is equal to 0 because Store $_{i t}=$ Freq $_{i t}$, which means perfectly disloyal customers. Conversely, if a customer buys at the same store in every purchase occasion, the value will converge to 1, the highest level of store loyalty.

We assume that customer utility from buying a product $b_{i t}^{*}$, the amount spent $p_{i t}$, and long-term store loyalty $p_{i t}$, are determined by such factors as customer characteristics, customer experience, store loyalty, and time effects. These relationships are modeled as follows, where the subscripts $b, p$, and $s l$ correspond to purchase incidence, purchase amount, and store loyalty, respectively; further, $e_{b i t}, e_{\text {pit }}$, and $e_{s c i t}$ are error terms that follow a multivariate normal distribution, $\mathrm{N}(0, \Sigma)$ :

$$
\begin{gathered}
b_{i t}^{*}=\text { Customer Characteristics }_{b i}+\text { Experience }_{b i t}+\text { Store Loyalty }_{b i t}+\text { Time Effect }_{\text {bit }}+\mathrm{e}_{\text {bit }} \\
p_{i t}=\text { Customer Characteristics }_{p i}+\text { Experience }_{p i t}+\text { Store Loyalty }_{\text {pit }}+\text { Time Effect }_{\text {pit }}+\mathrm{e}_{\text {pit }} \\
\qquad l_{i t}=\text { Customer Characteristics }_{\text {sli }}+\text { Experience }_{\text {slit }}+\text { Time Effect }_{\text {slit }}+\mathrm{e}_{\text {slit }}
\end{gathered}
$$

\subsection{Customer Characteristics}

We include the variables of gender, age, and device usage in customer characteristics. Denoting the intercepts by Int, the effect of customer characteristics can be written as follows:

$$
\begin{aligned}
& \text { Customer Characteristics }_{b i t}=\operatorname{Int}_{b t}+\beta_{b 1}^{c c} \mathrm{Gender}_{i}+\beta_{b 2}^{c c} \mathrm{Age}_{i}+\beta_{b 3}^{c c} \text { Device }_{i} \\
& \text { Customer Characteristics }_{p i t}=\text { Int }_{p t}+\beta_{p 1}^{c c} \text { Female }_{i}+\beta_{p 2}^{c c} \text { Age }_{i}+\beta_{p 3}^{c c} \text { Device }_{i} \\
& \text { Customer Characteristics }_{s l i t}=I n t_{s l t}+\beta_{s l 1}^{c c} \text { Female }_{i}+\beta_{s l 2}^{c c} \text { Age }_{i}+\beta_{s l 3}^{c c} \text { Device }_{i}
\end{aligned}
$$

We use a dummy variable for gender that equals 0 if a customer is a male and 1 if otherwise. Further, we follow the categorization of customers' age into Generation X and Generation Y (Dias, 2003), and use a dummy variable indicating whether a customer is younger than 35 years old (i.e., Generation Y) or older. Consistent with Bakewell and Mitchell (2003), we expect to observe different behavioral patterns between men and women. Finally, a dummy variable that indicates whether a customer uses a mobile device or a fixed PC to access the mall's website is included.

\subsection{Experience Effect}

Experience effect captures the influence of cumulative past shopping experiences of customers with the mall on current purchase behavior and store loyalty formation. In particular, we consider three shopping experience effects: cumulative purchase on deal, purchase amount, and purchase frequency. Cumulative deal proneness refers to a customer's buying experience during price promotion, which is defined as the percentage of products bought on promotion from the first purchase. Cumulative purchase amount and frequency are operationalized as the logarithmic of the total amount that has been spent, and the number of mall visits that have been made, by a customer up to a certain time. Thus, the experience effects are given as follows:

$$
\begin{aligned}
& \text { Experience }_{b i t}=\beta_{b 1}^{e} \text { Deal Proneness }_{i, t-1}+\beta_{b 2}^{e} \text { Amount }_{i, t-1}+\beta_{b 3}^{e} \text { Freq }_{i, t-1} \\
& \text { Experience }_{p i t}=\beta_{p 1}^{e} \text { Deal Proneness }_{i, t-1}+\beta_{p 2}^{e} \text { Amount }_{i . t-1}+\beta_{p 3}^{e} \text { Freq }_{i, t-1} \\
& \text { Experience }_{s l i t}=\beta_{s l 1}^{e} \text { Deal Proneness }_{i, t-1}+\beta_{s l 2}^{e} \text { Amount }_{i, t-1}+\beta_{s l 3}^{e} \text { Freq }_{i, t-1}
\end{aligned}
$$

\subsection{Store Loyalty Effect}

The effect of store loyalty on purchase incidence and purchase amount is decomposed into short- and long-term effects as follows: 


$$
\begin{aligned}
& \text { Store Loyalty }_{b i t}=\beta_{b 1}^{s l} \text { Short Term }_{i t}+\beta_{b 2}^{s l} \text { Long Term }_{i t} \\
& \text { Store Loyalty }{ }_{p i t}=\beta_{p 1}^{s l} \text { Short Term }_{i t}+\beta_{p 2}^{s l} \text { Long Term }_{i t}
\end{aligned}
$$

The short-term variable is defined as the proportion of amount spent by a customer at focal stores in the previous purchase occasion, which can be written as follows:

$$
\text { Short Term } \mathrm{it}_{\mathrm{it}}=\frac{F S_{-} I T E M_{i, t-1}}{\text { MALL_ITEM }_{i, t-1}}
$$

Here, FS_ITEM and MALL_ITEM are the amount spent at focal stores and the mall, respectively. Further, the long-term effect is captured by the lag of store loyalty variable in the equation (3); that is:

$$
\text { Long } \text { Term }_{i t}=1-\frac{\text { store }_{i, t-1}}{\text { Freq }_{i, t-1}}
$$

\subsection{Time Effect}

Additionally, we include a trend variable to capture the effect of the elapsed time since a new customer signed up for mall membership. We expect this variable to positively affect both purchase incidence and amount because customers' trust in the mall should increase as they continue buying from the mall.

$$
\begin{aligned}
\text { Time Effect }_{b t} & =\beta_{b 1}^{t e} t \\
\text { Time Effect }_{p t} & =\beta_{p 1}^{t e} t \\
\text { Time Effect }_{s l t} & =\beta_{s l 1}^{t e} t
\end{aligned}
$$

\section{Data}

The data used in the analysis were provided by an online shopping mall company through a data contest organized by the Joint Association Study Group of Management Science in Japan. The company's name is withheld for confidentiality purposes; however, it is one of the leading e-commerce firms selling fashion-related products, such as apparel and accessories. More than 900 independent tenant shops sell their products on the mall's website. Most of them sell originally branded products, meaning that no two shops sell the same products. The mall owner supports the businesses of its tenants by providing online information that helps customers find the products they wish to buy. In addition, the mall owner sends emails to its customers to cross-sell products or to provide price promotions.

The data contain a record of customers' purchases for one year. A total of 1,009,609 purchases were made by 101,480 customers during this period. The number of orders placed by each customer ranged from 1 to 1,717 . Those customers with a very high number of purchases were more likely to be businesses rather than individual customers. Since the focus of this study is on individual customer behavior, we decided to exclude business customers from our sample. To identify business customers, we considered extremely high purchase frequency data as outliers and used the Smirnov-Grubbs test to detect these outliers (Grubbs, 1950). The test resulted in the exclusion of customers who made 43 or more purchases. Since our focus is on new customers, whose store loyalty had not been formed prior to their first purchases, we only include those who signed up in the first month of the observation period. The final sample retained for the analysis was 465 . Given the average purchase rate of these customers, we aggregate the purchases into monthly data, resulting in 5,472 observations in total.

Table 1 shows the summary statistics of the sample in the data. The average purchase rate is 0.52 with a standard deviation of 0.18 . Average customers spend as much as 116,546 yen during the year, and the value ranges from 19,000 yen to 670,000 yen, indicating considerable heterogeneity in expenditures. The average value of store loyalty variable is relatively low (Mean $=0.30, \mathrm{SD}=0.23$ ), implying that a large portion of customers shopped in multiple stores during the observation period. However, the maximum value is 0.95 , which means that a number of customers are highly loyal to the focal stores. For the composition of customers by age, of the 465 customers, 270 are Generation Y. The percentage of customers who use mobile devices to access the website and place orders is $74 \%$. Further, average customers buy approximately $40 \%$ of the products during promotional periods; however, some customers never use price promotion, while others are totally deal-prone. 
Table 1. Summary Statistics of Data

\begin{tabular}{|c|c|c|c|c|c|}
\hline Variable & $\begin{array}{c}\text { Number of } \\
\text { Customers }(\%)\end{array}$ & Mean & Min & Max & SD \\
\hline Purchase Rate & & 0.52 & 0.17 & 1.00 & 0.18 \\
\hline Purchase Amount (yen) & & 116,546 & 19,000 & 670,000 & 92612 \\
\hline Store Loyalty & & 0.30 & 0.00 & 0.95 & 0.23 \\
\hline \multicolumn{6}{|l|}{ Gender } \\
\hline Male $($ Gender $=0)$ & $150(32.89)$ & & & & \\
\hline Female $($ Gender $=1)$ & $306(67.11)$ & & & & \\
\hline \multicolumn{6}{|l|}{ Generation } \\
\hline$Y($ Age $\leqq 35)$ & $270(59.21)$ & & & & \\
\hline$X($ Age $>35)$ & $186(40.79)$ & & & & \\
\hline Mobile Device Usage & & 0.74 & 0.00 & 1.00 & 0.40 \\
\hline Deal Proneness & & 0.40 & 0.00 & 1.00 & 0.34 \\
\hline
\end{tabular}

\section{Results}

We estimated the proposed model by using the Markov Chain Monte Carlo method with 10,000 iterations, where the first 5,000 were "burned-in" to eliminate the influence of initial values. We use the same estimation procedure as in Ansari et al. (2008). We confirmed the convergence of the chain by observing the variation of the posterior means.

\subsection{Hypothesis Testing}

The estimation results are represented in Table 2. As shown in the purchase incidence model, the estimates of short-term loyalty are significant, but with a negative sign $\left(s_{b 1}^{s l}=-8.264\right)$. Thus, purchase probability decreases with short-term loyalty, leading to the rejection of H1(a). By contrast, the results for the purchase amount model reveal that short-term loyalty positively influences purchase amount $\left(s_{p 1}^{s l}=7.166\right)$, which supports H1(b). For the effect of long-term store loyalty on purchase incidence, we find the estimate is positive, but insignificant $\left(s_{b 1}^{s l}=1.140\right)$. Thus, we reject $\mathrm{H} 2(\mathrm{a})$. However, this variable has a positive effect on purchase amount, as expected $\left(s_{p 2}^{s l}=4.936\right)$, and provides support for $\mathrm{H} 2(\mathrm{~b})$. The results reveal that store loyalty has a negative effect on purchase probability in the short-term, but this effect is not carried over in the long-term. In contrast, store loyalty appears to significantly affect purchase amount, both in the short- and long-term, with the immediate effect tending to be larger than the cumulative effect. The summary of the hypothesis testing is shown in Table 3.

Table 2 Parameter Estimates

\begin{tabular}{lcccccc}
\hline & \multicolumn{2}{c}{ Purchase Incidence } & \multicolumn{2}{c}{ Purchase Amount } & \multicolumn{2}{c}{ Store Loyalty } \\
\cline { 2 - 6 } & Mean & SD & Mean & SD & \multicolumn{2}{c}{ Mean } \\
\hline Variable & & & & & & \\
Intercept & $\mathbf{- 3 . 0 7 4}$ & $\mathbf{1 . 7 1 2}$ & $\mathbf{- 5 . 5 9 1}$ & $\mathbf{2 . 1 2 8}$ & $\mathbf{1 2 . 2 6 1}$ & $\mathbf{0 . 5 3 8}$ \\
Gender & $\mathbf{- 4 . 4 4 8}$ & $\mathbf{0 . 3 3 4}$ & $\mathbf{6 . 1 2 6}$ & $\mathbf{0 . 4 2 0}$ & $\mathbf{- 6 . 7 3 0}$ & $\mathbf{0 . 8 6 8}$ \\
Age & $\mathbf{5 . 2 7 6}$ & $\mathbf{0 . 9 6 5}$ & $\mathbf{2 . 4 8 0}$ & $\mathbf{0 . 5 0 8}$ & $\mathbf{3 . 5 7 5}$ & $\mathbf{0 . 6 3 6}$ \\
Mobile Device Usage & 0.205 & 0.875 & 2.079 & 1.537 & -0.836 & 0.481 \\
Deal Proneness & -1.005 & 0.866 & $\mathbf{- 3 . 4 4 7}$ & $\mathbf{1 . 3 1 9}$ & -0.821 & 0.493 \\
Cumulative Purchase Amount & $\mathbf{0 . 5 2 2}$ & $\mathbf{0 . 2 6 7}$ & -0.178 & 0.167 & $\mathbf{- 0 . 8 5 9}$ & $\mathbf{0 . 0 9 9}$ \\
Cumulative Purchase Frequency & $\mathbf{- 0 . 6 5 4}$ & $\mathbf{0 . 1 6 4}$ & $\mathbf{0 . 5 5 1}$ & $\mathbf{0 . 0 5 0}$ & $\mathbf{0 . 4 3 0}$ & $\mathbf{0 . 0 9 1}$ \\
Short-Term Store Loyalty & $\mathbf{- 8 . 2 6 4}$ & $\mathbf{0 . 5 4 4}$ & $\mathbf{7 . 1 6 6}$ & $\mathbf{0 . 4 1 9}$ & & \\
Long-Term Store Loyalty & 1.140 & 1.192 & $\mathbf{4 . 9 3 6}$ & $\mathbf{1 . 6 8 8}$ & $\mathbf{0 . 3 4 9}$ & $\mathbf{0 . 1 6 1}$ \\
Trend & $\mathbf{0 . 8 3 8}$ & $\mathbf{0 . 1 2 9}$ & $\mathbf{- 0 . 4 1 7}$ & $\mathbf{0 . 1 8 2}$ & $\mathbf{0 . 3 4 9}$
\end{tabular}

Note: bold fonts indicate significant estimates (i.e., their 95\% HPD intervals do not include 0 ).

Table 3. Summary of Hypothesis Testing Results

\begin{tabular}{ccccc}
\hline Hypothesis & Independent Variable & Dependent Variable & Expected Direction & Result \\
\hline H1(a) & Short-Term Store Loyalty & Purchase Incidence & $(+)$ & Not Supported \\
H1(b) & Short-Term Store Loyalty & Purchase Amount & $(+)$ & Supported \\
H2(a) & Long-Term Store Loyalty & Purchase Incidence & $(+)$ & Not Supported \\
H2(b) & Long-Term Store Loyalty & Purchase Amount & $(+)$ & Supported \\
\hline
\end{tabular}

6.2 Store Loyalty Formation

The results for the store loyalty formation model reveal that the effect of gender, age, cumulative purchase amount, cumulative purchase frequency, and time trend are significant. The estimate of gender is negative, indicating that male customers are more likely to become loyal to certain focal stores than female customers. Further, the estimate of age has a positive sign, which implies that store loyalty is more salient for Generation $\mathrm{X}$ customers than for Generation Y customers. Thus, older customers are likely to purchase products from a few 
focal stores, as compared to younger customers who tend to spread their purchases across several stores. Interestingly, we find that cumulative purchase amount and cumulative purchase frequency have the opposite signs. The former has a negative effect, and the latter has a positive effect, on store loyalty. The results indicate that customers who frequently buy in small amounts are more likely to become store-loyal than those who spend a high amount on each transaction, but do so less frequently. Further, we observe a positive effect of the time trend variable, which indicates that store loyalty increases with the relationship duration between the stores and the customers. In addition, the effects of mobile device usage and deal proneness are insignificant, indicating that these variables do not contribute to the formation of store loyalty.

\section{Discussion and Implications}

\subsection{Discussion}

In this study, we examine the relationship between store loyalty and mall loyalty of new customers patronizing an online shopping mall. We use purchase incidence and purchase amount as surrogates for behavioral mall loyalty. Further, we divide store loyalty into short- and long-term to capture the immediate and carry-over effect of this variable. The analysis reveals that purchase incidence is negatively affected by short-term store loyalty, but unaffected by long-term store loyalty. This result is contradictory to our expectation that both short- and long-term store loyalty increases purchase event probability. We conjecture this as a result of customers' buying characteristics in the fashion category. Since fashion is not a necessity, customers may have a limited budget to expend in this category. Therefore, high spending in focal stores would negatively affect subsequent purchase events because customers are inclined to balance their budgets. This might be particularly true in the online fashion market where customers are motivated to spend a high amount in a single transaction in order to avoid paying the shipping cost. By contrast, we find that purchase amount increases with both short- and long-term store loyalty, which supports our hypotheses. This result suggests that mall owners should take considerable account of customer loyalty toward their tenants because these attitudinal and behavioral aspects could be critical for future revenue.

This study also identifies the influence of several variables in inducing long-term store loyalty. First, we confirm the significant role of gender, where men are more likely to be store-loyal than women. The result is in line with previous findings that female customers perceive a higher level of risk in online stores than do male customers (Garbarino \& Strahilevitz, 2004). In fact, there is evidence that women are less satisfied than men with the online shopping experience (Rodgers \& Harris, 2003), which is consistent with our findings. The notion that women exhibit stronger loyalty to individual stores has empirical support from a study by Melnyk, van Osselaer, and Bijmolt (2009). Further, older customers appear to have higher store loyalty than do younger customers. We interpret this as stemming from the fact that older customers tend to perceive a higher risk, and bear higher searching cost, when shopping at online stores (Lian \& Yen, 2014). Thus, they would prefer repurchasing in familiar stores, rather than buying from less familiar stores, even when the stores sell more attractive product offerings. Of particular interest, we observe a significant negative effect of cumulative purchase amount and a positive effect of cumulative purchase frequency. This implies that customers who spend higher amounts on each transaction are likely to purchase in different stores, perhaps because they are more involved in the buying process and are motivated to buy in a store that maximizes their utility. In contrast, customers who frequently buy, but in smaller amounts, tend to purchase from familiar stores. Finally, we confirm the positive effect of time trend, which reflects the increasing customer familiarity with the stores over time.

\subsection{Implications}

We argue that our findings have several important implications for academia, as well as practitioners. With regard to theoretical implications, this study adds to the literature's novel understanding of how store loyalty affects behavioral mall loyalty in the short- and long-term. While most of the extant studies focus on either store loyalty or mall loyalty, this study addresses the nature of the dynamic relationship between the two. Using actual purchase history data, our analysis shows that store loyalty has an immediate negative effect on purchase incidence, but increases the amount spent by customers given a purchase. Furthermore, this study provides a better understanding of how store loyalty is developed over time, providing useful information for a marketer to build and maintain customer relationships. This is particularly critical in the development of customer loyalty programs where firms want to know the appropriate target customers for such a program. In addition, our findings may be useful to anticipate the sales impact of cross-selling initiatives. In an online shopping mall, it is common practice that the mall owner entices customers to buy additional products from tenant shops by a direct mailing or automated recommendation system. Encouraging customers to buy in familiar stores will increase their store loyalty, and eventually induce customers to spend more money in the future. However, it should be 
noted that this may lead to an immediate decrease in sales after a cross-selling campaign, but will increase revenue in the long-term.

\section{Conclusion}

This empirical study reveals that customer loyalty toward some focal stores in an online shopping mall affect behavioral patterns over time. In the short-term, store loyalty decreases customer purchase incidence. However, given a purchase, the amount spent is higher for customers with higher store loyalty. Further, it was shown that the formation of long-term store loyalty depends on gender, age, cumulative purchase amount, cumulative purchase frequency, and time trend. These findings are particularly important for mall owners who want to increase their sales through customer loyalty.

However, we also note some limitations of this study. First, we only investigated the impact of store loyalty in the fashion category. Thus, our result may lack generalizability. Further investigation into different product categories is needed to provide external validity. Second, due to data availability, we were restricted to only exploring the behavioral aspect of store loyalty. However, as suggested by previous studies, to examine store loyalty properly, we need to account for customers' attitudes toward the store under consideration. Finally, for the same reason, we are unable to include the role of product involvement, which could be influential in the development of store loyalty (Dick \& Basu, 1994). Future research should combine purchase history data and survey data to address these concerns.

\section{Acknowledgments}

This research was supported by Japan Society for the Promotion of Science, KAKENHI [grant number 17H02573].

\section{References}

Adkins, L. M. L., Burgess, B., \& Wesley, S. (2002). Expanding the loyalty concept to include customer preference for a shopping mall. International Review of Retail, Distribution and Consumer Research, 12(3), 225-236. https://doi.org/10.1080/09593960210139643

Ahn, T., Ryu, S., \& Han, I. (2003). The impact of the online and offline features on the user acceptance of internet shopping malls. Electronic Commerce Research and Applications, 3(4), 405-420. https://doi.org/10.1016/j.elerap.2004.05.001

Ailawadi, K., Pauwels, K., \& Steenkamp, J. B. E. M. (2008). Private-label use and store loyalty. Journal of Marketing, 72(6), 19-30. https://doi.org/10.1509/jmkg.72.6.19

Ansari, A., Mela, C. F., \& Neslin, S. A. (2008). Customer Channel Migration, Journal of Marketing Research, 45(1), 60-76. https://doi.org/10.1509/jmkr.45.1.60

Babin, B. J., \& Attaway, J. S. (2000). Atmospheric affect as a tool for creating value and gaining share of customer. Journal of Business Research, 49(2), 91-99. https://doi.org/10.1016/S0148-2963(99)00011-9

Bakewell, C., \& Mitchell, V. W. (2003). Generation Y female consumer decision-making styles. International Journal of Retail \& Distribution Management, 31(2), 95-106. https://doi.org/10.1108/09590550310461994

Bloemer, J., \& Ruyter, K. D. (1998). On the relationship between store image, store satisfaction and store loyalty. European Journal of marketing, 32(5/6), 499-513. https://doi.org/10.1108/03090569810216118

Business Insider. (2017). “Amazon accounts for $43 \%$ of US online retail sales," Available at: http://www.businessinsider.com/amazon-accounts-for-43-of-us-online-retail-sales-2017-2.

Chebat, J. C., Hedhli, K. E., \& Sirgy, M. J. (2009). "How does shopper-based mall equity generate mall loyalty? A conceptual model and empirical evidence," Journal of Retailing and Consumer Services, 16(1), 50-60. https://doi.org/10.1016/j.jretconser.2008.08.003

Corstjens, M., \& Lal, R. (2000). Building Store Loyalty through Store Brands, Journal of Marketing Research, 37(3), 281-292. https://doi.org/10.1509/jmkr.37.3.281.18781

Dias, P. L. (2003). Generational buying motivations for fashion. Journal of Fashion Marketing and Management: An International Journal, 7(1), 78-86. https://doi.org/10.1108/13612020310464386

Dick, A. S., \& Basu, K. (1994). Customer loyalty: toward an integrated conceptual framework. Journal of the Academy of Marketing Science, 22(2), 99-113. https://doi.org/10.1177\%2F0092070394222001

Erdil, T. S. (2015). Effects of customer Brand Perceptions on Store Image and Purchase Intention: An Application in Apparel Clothing. Procedia Social and behavioral Sciences, 207(20), 196-205. 
https://doi.org/10.1016/j.sbspro.2015.10.088

Finn, A., \& Louviere, J. (1996). Shopping center image, consideration, and choice: anchor store contribution. Journal of Business Research, 35(3), 241-251. https://doi.org/10.1016/0148-2963(95)00129-8

Fisher, R. J., \& Dubé, L. (2005), Gender Differences in Responses to Emotional Advertising: A Social Desirability Perspective, Journal of Consumer Research, 31(4), 850-858. https://doi.org/10.1086/426621

Garbarino, E., \& Johnson, M. S. (1999). The different roles of satisfaction, trust, and commitment in customer relationships. Journal of Marketing, 63(2), 70-87. https://doi.org/10.2307/1251946

Garbarino, E., \& Strahilevitz, M. (2004). Gender differences in the perceived risk of buying online and the effects of receiving a site recommendation. Journal of Business Research, 57(7), 768-775. https://doi.org/10.1016/S0148-2963(02)00363-6

Grubbs, F. E. (1950). Sample criteria for testing outlying observations. Annals of Mathematical Statistics, 21(1), 27-58. https://doi.org/10.1214/aoms/1177729885

Haj-salem, N., Chebat, J. C., Michon, R., \& Oliveira, S. (2016). Why male and female shoppers do not see mall loyalty through the same lens? The mediating role of self-congruity. Journal of Business Research, 69(3), 1219-1227. https://doi.org/10.1016/j.jbusres.2015.09.011

Haytko, D. L., \& Baker, J. (2004). It's all at the Mall: Exploring Adolescent Girls' Experiences. Journal of Retailing, 80(1), 67-83. https://doi.org/10.1016/j.jretai.2004.01.005

Hedhli, K. E., Chebat, J. C., \& Sirgy, M. J. (2013). Shopping well-being at the mall: Construct, antecedents, and consequences. Journal of Business Research, 66(7), 856-863. https://doi.org/10.1016/j.jbusres.2011.06.011

Hendershott, P. H., Hendershott, R. J., \& Hendershott, T. J. (2001). The future of virtual malls. Real Estate Finance, 18(1) 25-32.

Kim, J., Jin, B., \& Swinney, J. L. (2009), The role of e-tail quality, e-satisfaction and e-trust in online loyalty development process. Journal of Retailing and Consumer Services, 16(4), 239-247. https://doi.org/10.1016/j.jretconser.2008.11.019

Kim, Y. M., \& Shim, K. Y. (2002). The influence of internet shopping mall characteristics and user traits on purchase intent. Irish Marketing Review, 15(2), 25-34.

Koo, D. M. (2006). The fundamental reasons of e-consumers' loyalty to an online store. Electronic Commerce Research and Applications, 5(2), 117-130. https://doi.org/10.1016/j.elerap.2005.10.003

Kumar, V., \& Shah, D. (2004). Building and Sustaining Profitable Customer Loyalty for the 21st Century. Journal of Retailing, 80(4), 317-329. https://doi.org/10.1016/j.jretai.2004.10.007

Kumar, V., Pozza, I. D. \& Ganesh, J. (2013). Revisiting the satisfaction-loyalty relationship: empirical generalizations and directions for future research, Journal of Retailing, 89(3), 246-262. https://doi.org/10.1016/j.jretai.2013.02.001

Lian, J. W., \& Yen, D. C. (2014). Online shopping drivers and barriers for older adults: Age and gender differences. Computers in Human Behavior, 37, 133-143. https://doi.org/10.1016/j.chb.2014.04.028

Lin, G. T. R., \& Sun, C. C. (2009). Factors influencing satisfaction and loyalty in online shopping: an integrated model. Online Information Review, 33(3), 458-475. https://doi.org/10.1108/14684520910969907

Majumdar, A. (2005). A model for customer loyalty for retail stores inside shopping malls: An Indian perspective. Journal of Services Research, (Special Issue), 47-64.

Melnyk, V., van Osselaer, S. M. J., \& Bijmolt, T. H. A. (2009). Are women more loyal customers than men? Gender differences in loyalty to firms and individual service providers. Journal of Marketing, 73(4), 82-96. https://doi.org/10.1509/jmkg.73.4.82

Meyers-Levy, J., \& Maheswaran, D. (1991). Exploring Differences in Males' and Females' Processing Strategy. Journal of Consumer Research, 18(1), 63-70. https://doi.org/10.1086/209241

Meyers-Levy, J., \& Sternthal, B. (1991). Gender Differences in the Use of Message Cues and Judgments. Journal of Marketing Research, 28(1), 84-96. https://doi.org/10.2307/3172728

Mittal, V., \& Kamakura, W. A. (2001). Satisfaction, repurchase intent, and repurchase behavior: Investigating the moderating effect of customer characteristics. Journal of Marketing Research, 38(1), 131-142. https://doi.org/10.1509/jmkr.38.1.131.18832 
Rabbanee, F. K., Ramaseshan, B., Wu, C., \& Vinden, A. (2012). Effects of store loyalty on shopping mall loyalty. Journal of Retailing and Consumer Services, 19(3), 271-278. https://doi.org/10.1016/j.jretconser.2012.02.001

Rodgers, S., \& Harris, M. A. (2003). Gender and e-commerce: An exploratory study. Journal of Advertising Research, 43(3), 322-329. https://doi.org/10.1017/S0021849903030307

Samadi, M., \& Yaghoob-Najadi, A. (2009). A survey of the effect of consumers' perceived risk on purchase intention in E-shopping. Business Intelligence Journal, 2(2), 261-275.

Semeijn, J., van Riel, A. C., van Birgelen, M. J., \& Streukens, S. (2005). E-services and offline fulfilment: how e-loyalty is created. Managing Service Quality: An International Journal, 15(2), 182-194. https://doi.org/10.1108/09604520510585361

Sirohi, N., McLaughlin, E. W., \& Wittink, D. R. (1998). A Model of Consumer Perceptions and Store Loyalty Intentions for a Supermarket Retailer. Journal of Retailing, 74(2), 223-245. https://doi.org/10.1016/S0022-4359(99)80094-3

Srinivasan, S. S., Anderson, R, \& Ponnavolu, K. (2002). Customer loyalty in e-commerce: An exploration of its antecedents and consequences. Journal of Retailing, 78(1), 41-50. https://doi.org/10.1016/S0022-4359(01)00065-3

Stranahan, H., \& Kosiel, D. (2007). E-tail spending patterns and the importance of online store familiarity, Internet Research, 17(4), 421-434. https://doi.org/10.1108/10662240710828076

Swinyard, W. R. (1993). The effects of mood, involvement and quality of store experience on shopping intentions. Journal of Advertising Research, 20(1), 271-280. https://doi.org/10.1086/209348

Umashankar, N., Bhagwat, Y., \& Kumar, V. (2017). Do loyal customers really pay more for services? Journal of the Academy of Marketing Science, 45(6), 807-826. https://doi.org/10.1007/s11747-016-0491-8

Wang, R. J. H., Malthouse, E. C., \& Krishnamurthi, L. (2015). On the Go: How Mobile Shopping Affects Customer Purchase Behavior. Journal of Retailing, 91(2), 217-234. https://doi.org/10.1016/j.jretai.2015.01.002

Wu, L. Y., Chen, K. Y., Chen, P. Y., \& Cheng, S. L. (2014). Perceived value, transaction cost, and repurchase-intention in online shopping: a relational exchange perspective. Journal of Business Research, 67(1), 2768-2776. https://doi.org/10.1016/j.jbusres.2012.09.007

\section{Copyrights}

Copyright for this article is retained by the author(s), with first publication rights granted to the journal.

This is an open-access article distributed under the terms and conditions of the Creative Commons Attribution license (http://creativecommons.org/licenses/by/4.0/). 